\title{
ZiZEK COM LACAN EM: KANT SEM SADE. LIBERDADE COMO REAPROPRIAÇÁO DO GOZO
}

\author{
Fernando Facó de Assis Fonseca ${ }^{1}$ \\ Hildemar Luiz Rech ${ }^{2}$
}

\begin{abstract}
Resumo: Neste artigo, pretendemos trabalhar, a partir de uma leitura de Zizek e Lacan, a perspectiva radical de liberdade como superação da dialética entre a Lei moral kantiana e o gozo sádico. Para isso, procuramos primeiramente mostrar como Lacan articula a relação de Kant com Sade, para, em seguida, pensar como, segundo Zizek, o psicanalista encontra uma saída para o princípio de liberdade kantiana, a partir da ética do desejo puro, o que nos permitirá pensar um Kant sem Sade.
\end{abstract}

Palavras-Chave: Lei Moral. Desejo. Gozo. Liberdade.

\section{INTRODUÇÃo}

Em 1963, Lacan publica um texto considerado por muitos como um dos mais herméticos de seus Escritos, e cuja dificuldade se expressa já no título: Kant com Sade. A impressionante combinação desses dois autores nos leva diretamente à questão de como é possível o arauto da moralidade, na era moderna, para quem a liberdade está incondicionalmente ligada ao dever moral, à intransigência do imperativo categórico, formar par com o seu extremo oposto, a maior expressão literária da perversão e da libertinagem incontida. Por isso, Zizek (1998) assinala que essa dupla, de todas que já se formaram, ao longo dos últimos anos (como Freud e Lacan, Marx e Lenin etc.), é, com efeito, a mais problemática do pensamento moderno. Mas, longe de essa estranha associação ser um mero devaneio do psicanalista, devemos louvar aqui seu gênio: Lacan pôde extrair do seio do rigor moral kantiano o seu núcleo obsceno, excessivo e perverso, que permanecia oculto para a tradição, e cuja melhor

\footnotetext{
${ }^{1}$ Doutor em Filosofia da Educação pela Universidade Federal do Ceará-UFC. Possui mestrado em Filosofia pelo programa Erasmus Mundus Europhilosophie (2010).] Tem também mestrado em Filosofia pela Universidade Federal do Ceará (2008). E-mail: fernandofaco@hotmail.com http://dx.doi.org/10.1590/S0101-31732017000100009

2 Doutor em Ciências Sociais pelo IFCH da UNICAMP, SP, com sandwish pela Universidade de Manchester, Inglaterra; Pesquisador e Professor Associado IV no Departamento de Fundamentos da Educação e na Linha de Pesquisa de Filosofia e Sociologia da Educação no Programa de Pós-Graduação em Educaçăo, FACED-UFC. E-mail: hluizrech@gmail.com
} 
representação não é outra senão a figura libertina de Sade. Zizek (1998) tem, portanto, plena razão ao afirmar que essa dupla Kant-Sade, que representa a essência de nossa eticidade moderna, é um típico caso de julgamento infinito hegeliano hegeliano, ${ }^{3}$ em cujo núcleo se concentram os radicais opostos de uma sublime atitude ética desinteressada com o prazer sexual fundado nas experiências sádicas de extrema violência.

De uma maneira inequívoca, essa contradição incutida no seio da própria modernidade nos leva direto às questóes abertas pelos teóricos da Escola de Frankfurt ${ }^{4}$ sobre Esclarecimento e barbárie, ou seja, a respeito da íntima relação entre os ideais erguidos pela razão iluminista e as grandes hecatombes ocorridas no século XX (as duas Grandes Guerras, o holocausto, a bomba atômica etc.). Nesse sentido, é válido perguntar: seria lícito reconhecer uma linha que vai do formalismo ético kantiano diretamente à indústria da morte a sangue-frio, em Auschwitz? Ou, ainda, seriam os campos de concentração, ali onde o genocídio era executado segundo uma lógica burocrática, o resultado direto da insistência no projeto de uma razão esclarecida e emancipadora da modernidade? (ZIZEK, 1998). Convém, então, abordar esse questionamento, enfocando o paradoxo da moralidade kantiana, a fim de discutirmos como é possível rearticular o conceito de liberdade, assimilando integralmente essa contradição constituinte. Todavia, para responder a essas questóes cumpre, pois, entender como foi possível unir Kant e Sade numa mesma linha de perspectiva.

\section{O FORMALISMO ÉTICO DE KANT}

Para os leitores minimamente versados em Kant, não deve ser difícil reconhecer a mudança estrutural que seu pensamento acarretou, no campo da filosofia moral. Para sermos claros e sucintos, basta dizer que a moral kantiana rompe drasticamente com duas frentes teóricas: a tradição ético-cosmológica dos antigos e a visão utilitarista dos filósofos pragmáticos, na modernidade. A fim de compreender o alcance dessa ruptura, é imprescindível ressaltar o

\footnotetext{
${ }^{3}$ Em Hegel (2003), esse juízo (julgamento) infinito é também conhecido como juízo especulativo, uma espécie de juízo que toca na própria dimensão ontológica da realidade. O juízo especulativo hegeliano é, pois, a própria coincidência dos opostos, cujo paradoxo é inapreensível pelo padrão de funcionamento do entendimento. Por sua articulação, elementos de naturezas totalmente incompatíveis se fundem um no outro, provocando um sentimento de estranheza inconciliável. Eis, portanto, alguns desses juízos, extraídos da filosofia hegeliana, que Zizek destaca, ao longo de sua obra: "O Espírito é um osso", "o eu é o dinheiro", o "Estado é um monarca", "Deus é Cristo" etc.

${ }^{4}$ Refiro-me especialmente aos teóricos Adorno, Horkheimer, Marcuse e Benjamin.
} 
profundo impacto que a ciência moderna exerceu em todos os domínios da humanidade, inclusive e sobretudo na esfera da filosofia prática. Nesse sentido, com o advento das ciências modernas, o mundo passa a ser compreendido como um espaço neutro, onde os corpos se movimentam apenas por puras relaçóes de forças - como documentam as leis da mecânica de Newton. Assim, a natureza já não pode mais representar um modelo de cosmos bom e harmonioso, cuja forma teria por missão servir de ideal à práxis moral. Diante disso, a moral dos antigos sofre um golpe profundo e irreversível: a visão cosmológica da natureza, que norteou os fundamentos da ética pagá, se transforma, na modernidade, num sistema mecânico insípido, isento de qualquer sentido último ou densidade substancial. O que está em jogo aqui não é mais o conteúdo significativo do universo, mas o sistema formal de leis que governam sua estrutura. E tal formalidade, própria do mundo moderno cujo foco agora se concentra eminentemente no método, e não mais no objeto da ciência -, leva, portanto, Kant a reconduzir a moral para uma base também formal, desvinculada assim de qualquer tese substancialista mais profunda. Se Bacon (2014), em seu Novo Órganon, ao subjugar a natureza, procura libertar o homem no campo do conhecimento, Kant procura libertar o homem no campo da moral. À medida que o homem se torna autônomo em relação à natureza, ele deve impor a si mesmo uma moral autônoma, sem pressupostos e sem vínculos metafísicos. Ou seja, uma moral emancipada, radicalizada na própria esfera da finitude humana.

Contudo, o que dizer das éticas utilitaristas? Elas também não seriam a construção de um projeto de uma ética moderna, pós-metafísica, livres da ilusão ético-cosmológica dos antigos? Sim. Apesar disso, a ética utilitarista não é uma ética eminentemente antropocêntrica, fundada na liberdade e na universalidade da espécie humana. É certo que os filósofos utilitaristas sucessores do britânico Jeremy Bentham - procuram adotar um padrão de medida ético-moral embasado numa metodologia com rigor científico - sem apelar, com isso, para princípios metafísicos ou teológicos. No entanto, o método estipulado por eles não chega a ser, segundo Kant (2011b), verdadeiramente universal. O problema reside no fato de os utilitaristas não se desprenderem completamente das condiçóes patológicas que orientam as açôes humanas. Embora eles aleguem um total descompromisso com interesses egoístas, narcísicos etc., e que seu propósito seja, em última instância, um legítimo altruísmo, o que constatamos aqui é um resultado profundamente ambíguo: ao empregar, por exemplo, o árduo cálculo do prazer e do desprazer como propósito ético, o vínculo patológico que orienta a práxis implica, em últi- 
ma instância, a negação de qualquer ascensão ao princípio moral de validade universal.

Para Kant (2011b), não há universalidade moral enquanto não houver um esvaziamento completo da carga patológica que orienta minha ação. Querer para o outro o mesmo que se quer para si continua a ser, mesmo que disfarçadamente, uma injunção radicalmente egoísta. Por isso, Lacan (1959-60/1988) está correto em afirmar, no seu Seminário sobre a ética na psicanálise, que “[...] meu egoísmo se satisfaz extremamente bem com um certo altruísmo, com aquele que se situa no nível do útil, e é precisamente o pretexto por meio do qual evito abordar o problema do mal que desejo, e que deseja o meu próximo." (LACAN, 1959-60/1988, p. 228). Não haveria, nesse sentido, um prazer excessivamente egoísta em toda ação altruísta? É como se o que eu estabeleço como fim moral universal fosse apenas uma projeção pessoal pautada no sentimentalismo idiossincrático. Assim, o desafio propriamente ético que se coloca aqui é: como sair desse ciclo, ou seja, como alcançar um nível ideal de ação universal e impessoal, desvinculada de toda e qualquer inclinação patológica? Ou, ainda: como estabelecer um tribunal idôneo, justo e universal, que possa ser capaz de julgar uma ação verdadeiramente ética? Somente no imperativo moral é que atingimos a verdadeira universalidade, haja vista que seu imperativo formal é pautado unicamente no dever imposto pela razáo universal. Trata-se de uma proposta de uma moral deontológica, cujo prefixo grego deon, que significa dever, obrigação, sugere uma ação fundada basicamente no dever à Lei universal. Dessa forma, Kant (2011b, p. 62) enfatiza que "[...] o imperativo categórico é portanto só um único, que é este: Age apenas segundo uma máxima tal que possas ao mesmo tempo querer que ela se torne lei universal."

\section{O OBJETO DA MORAL KANTIANA}

Podemos, portanto, concluir que, diferentemente do que prega o senso-comum, ser livre não é seguir indiscriminadamente as leis fisiológicas que submetem a vontade ao objeto, mas justamente o contrário: como destaca Vladimir Safatle (2003, p. 206), “[...] só há liberdade quando o sujeito pode determinar de maneira autônoma um objeto à vontade. A fim de produzir tal determinação, ele deve se apoiar na razão contra os impulsos patológicos do desejo." Desse modo, no lugar de um desejo determinado empiricamente, por um objeto particular, a liberdade corresponde à vontade pela pura forma da Lei universal, que, nesse caso, é completamente vazia de determinação. E 
é somente através desse vazio, "[...] dessa rejeição radical da série de objetos patológicos, que a conduta humana com seu sistema de decisóes pode ser outra coisa que o simples efeito da causalidade natural." (SAFATLE, 2003, p. 207).

Porém, pensar uma vontade desprovida de objeto não seria um caso claro de contradictio in adjecto? Afinal, toda vontade não é vontade de alguma coisa? Com efeito. E, nesse sentido, é preciso determinar qual o objeto que melhor se enquadra no modelo da vontade livre. Para isso, Kant introduz o conceito de das Gute: "[...] um bem para além do sentimento utilitário de prazer." (SAFATLE, 2003, p. 207). Mas que espécie de objeto é esse, das Gute? Para responder, cabe fazer aqui uma rápida diferenciação entre duas espécies de bem: das Gute e das Wohl. Das Gute representa o bem supremo da lei moral, ao passo que das Wohl consiste no bem-estar do sujeito patologizado. Em consequência, a fim de erradicar qualquer referência patológica que contamine com elementos empíricos a pureza da universalidade moral, devemos conceber das Gute - diferentemente de das Wohl-como um bem para além de qualquer princípio de prazer envolvido com o exercício da lei moral. Em suma: enquanto das Wohl designa o bem-estar, das Gute designa o bem-para-além-do-bem-estar. Das Gute, portanto, corresponde à injunção ética suprema do imperativo categórico, uma injunção radicalmente desprovida de qualquer sensação de bem-estar. Por isso, como ressalta Lacan (1963/1998), das Gute é o bem que se ouve dentro de nós como a voz proferida pela razáo, a voz da consciência.

No entanto, no que consistiria pensar um objeto da vontade livre, das Gute, cuja natureza não pode ser intuitivamente assimilada, ou seja, não pode ser formalizada segundo as formas a priori da intuiçáo sensível (tempo e espaço)? Ora, para Kant, como ressalta Safatle (2003, p. 208), “[...] a vontade que quer das Gute quer apenas uma forma de agir, uma forma específica para a ação, e não um objeto empírico privilegiado." Conclusão: o objeto da vontade livre é a pura forma da Lei, e "[...] a forma dessa lei é também sua única substância." (LACAN, 1963/1998, p. 770). Para dizê-lo em outros termos, não estamos lidando aqui com um objeto de natureza empírica, dotado de um conteúdo específico etc., pelo contrário, estamos lidando com um objeto cuja natureza é estritamente formal. Kant enfatiza (2011a, p. 56): “[...] a lei da vontade pura, que é livre, póe esta numa esfera diversa da empírica, e a necessidade que ela expressa, já que não deve ser nenhuma necessidade natural, tem que consistir meramente em condiçóes formais de possibilidade de uma lei em geral." 
Na Metafisica dos Costumes, Kant (2008, p. 62-63) deixa claro que a vontade corresponde à "[...] faculdade do desejo cujo fundamento determinante se encontra na razão do sujeito", ou seja, na própria capacidade de determinar a escolha e, por essa razáo, ela não possui um fundamento determinante. Entretanto, esse nítido contraste entre uma vontade livre, que visa à pura forma da Lei, e o desejo, que corresponde às inclinaçóes patológicas do sujeito fenomênico, pode sofrer uma complicação aqui. E se, no exato momento em que todo desejo empírico é completamente expurgado do código universalizante da Lei moral, surgisse um desejo ainda mais avassalador? E se essa supressão completa de todo e qualquer conteúdo patológico gerasse, em contrapartida, não uma vontade livre (de objeto), mas sim um novo desejo cujo objeto fosse a própria forma da Lei? Dito de outra forma, quando Kant purifica o dever moral de todo conteúdo patológico, ou seja, dos desejos empíricos que corrompem a universalidade da Lei moral com inclinaçôes idiossincráticas e utilitaristas, o resultado é o surgimento de uma vontade livre, totalmente desprovida de objeto, vinculada unicamente à pura forma da Lei. Porém, segundo Lacan (1963/1998), o que Kant não percebe é que, nesse momento, quando se elimina do campo da universalidade moral todo objeto patológico em função de uma vontade livre que quer simplesmente a pura forma da Lei, ele automaticamente eleva essa própria forma da Lei moral à condição de um objeto inalcançável, impossível. Ou seja, ele não vê que a própria forma da Lei é o objeto par excellence do desejo, o qual impele uma depuração furiosa e compulsiva de todo conteúdo empírico que macula seu $a$ priori transcendental.

E é exatamente aqui que Kant trai a si mesmo: ele não assume a possibilidade de que a pura forma da Lei possa ainda servir de objeto para o desejo. Em outras palavras, Kant não reconhece (ou melhor, recalca) que o próprio estatuto da Lei moral, sua condição puramente formal, se apresenta de maneira essencialmente ambígua em relação ao desejo: no momento em que a pura forma da Lei impele duramente à rejeição de todo desejo patológico, a dimensão formal da Lei continua a servir como objeto primordial do desejo humano. Dessa forma, Kant recua diante de sua própria injunção moral. Ou seja, uma vez que a forma da Lei ainda serve como objeto de desejo, significa então que Kant não alcança uma radicalização rigorosa de seu próprio imperativo categórico, qual seja, o de garantir uma autonomia moral para além de toda e qualquer dependência do objeto (ainda que este seja identificado como a pura forma da Lei). 


\section{KANT COM SADE}

Portanto, a questáo fundamental agora é compreender o que de fato une Kant a Sade. Comecemos, entấo, atentando para o seguinte: embora Kant insista na lacuna entre a pura forma da lei moral e os sentimentos patológicos, existe um sentimento que o sujeito necessariamente experimenta, quando confrontado com a injunção do imperativo categórico: a dor da humilhação (ZIZEK, 1998). Ocorre que a voz interior da consciência se revela como uma voz implacável, uma voz que exige, sem concessão, que lutemos - e que até mesmo nos violentemos - contra os impulsos patológicos orientados pelo princípio de prazer. Dito de forma mais concisa, o essencial é que, segundo Zizek (2012a, p. 562), a dor não é apenas um sentimento fenomênico, entre outros, mas um modo fenomenal privilegiado, "[...] em que a negatividade pode ser experimentada”. Aqui, Zizek segue pista de Heidegger, para quem, na sua atenta leitura da Crítica da Razão Prática, a dor consistiria na única emoção transcendental, a priori, “[...] a emoção do meu eu patológico sendo humilhado pela injunção da lei moral.” (ZIZEK, 2012a, p. 562). Assim, para Kant (2007), o significado de perfectibilidade da esfera ética implica uma rigorosa disciplina e submissão dos sentidos à razão universal. Isto é, o homem conquista a sua liberdade lutando contra si mesmo, ou melhor, se educando e impondo a si um regime disciplinar ininterrupto. É por essa razão que educação é um termo que tem sentido somente para seres humanos, já que, na base de sua dita "natureza", lidamos com um descarrilamento estrutural - ou, melhor dizendo, não natural.

Em seus escritos antropológicos, Kant sublinha que o animal humano precisa de uma força disciplinar para domar essa "insubordinação" constitutiva de sua "natureza". Como atesta, nesta passagem: "[...] o ser humano é a única criatura que deve ser educada. Por educação queremos dizer especificamente cuidado (manutenção, suporte), disciplina (treinamento) e instrução, juntamente com formação." (KANT, 2007, p. 437). E, aqui, Kant é mais rousseauniano do que nunca. Foi Rousseau quem primeiro estabeleceu essa relação indissociável entre liberdade e perfectibilidade moral. Para ele, a liberdade é uma condição estritamente humana, pois somente o homem possui a capacidade intrínseca de se aperfeiçoar, ao longo de sua existência, ao passo que o animal, guiado desde a origem de modo instintivo pela natureza, é, digamos, perfeito desde sempre (FERRY, 2012. p. 74). Isso testemunha o fato de que o elo perdido entre natureza e cultura é um elo perdido desde sempre. Não há base natural do homem; há, nele, uma vocação antinatural, manifestada por um excesso disjuntivo, inquietante e violento, e 
que está ausente nos animais. Eis o principal motivo da distinção freudiana entre instinto e pulsão: enquanto o instinto possui um télos próprio, incutido na biologia do animal, a pulsão é, pelo contrário, completamente desprovida de horizonte, uma espécie de propulsão libidinal cuja única meta é a pura e eterna repetição cíclica. Há, portanto, uma disfunção constitutiva inerente ao próprio homem, que desregula e póe abaixo todo o trabalho edificante $\mathrm{e}$ harmonioso da natureza. E, por essa razão, a liberdade só é possível a partir de uma força disciplinar implacável sobre o homem.

No entanto, Lacan identifica com muita perspicácia a fina correlação entre a universalidade da lei moral e esse excesso insubordinável do homem. A problemática que ele levanta concerne, então, ao fato de que a lei moral kantiana náo atua de sorte a abrandar esse excesso, como se tratasse de duas forças antagônicas. Pelo contrário, a lei moral é pressuposta por esse excesso, ela só se torna possível contra o pano de fundo de um descarrilamento constitutivo, de uma compulsão à repetição puramente mecânica. Nesse sentido, torna-se impossível manter a dicotomia clássica entre o animal humano, patologizado, e o sujeito transcendental, racional, como se estivéssemos lidando com duas forças contrárias, travando uma luta eterna entre elas: Lei moral e compulsão à repetição são, a rigor, um só princípio, porém, cuja identidade é cindida por uma lacuna irredutível, paraláctica. Assim, se, por um lado, a essência da liberdade em Kant é numênica, por outro, a condição material dessa liberdade reside no próprio desvio pulsional que lhe serve de suporte. Desse modo, no lugar de elevar o sujeito a um autocontrole pleno sobre si, o imperativo categórico de Kant só faz manter vivo, a pleno vapor, a incessante compulsão à repetição. E o problema que Lacan identifica na filosofia prática de Kant é precisamente o fato de o filósofo escamotear, ou melhor, recalcar essa lacuna. E é exatamente aqui que Sade entra em cena.

Do outro lado da medalha, Sade apresenta a mesma fórmula kantiana, mas numa lógica invertida. Enquanto Kant tematiza o sentimento de dor e humilhação somente para ressaltar o conteúdo edificante da lei moral (o sentimento de respeito), Sade apresenta o que essa operação tem de oculto e obsceno. É como se Sade revelasse a Kant o que ele evita reconhecer em seu próprio arcabouço teórico. Ou seja, Sade torna transparente o fora-da-lei que habita na própria lei. Zizek (1992, p. 65) assevera: “No começo' da lei há um certo fora-da-lei, um certo real da violência que coincide com o próprio ato de instauração da lei [...] [o] desmentido desse avesso da lei. É em razão desse desmentido que devemos ler 'Kant com Sade'." 
Pode-se, então, afirmar que Kant e Sade são frente e verso da mesma ideia. Vejamos por este ângulo: numa certa perspectiva, tem-se um quadro vazio, puramente formal, que exige inflexivelmente o exercício de um dever moral universal, mas que, por sua vez, não dá pistas de como cumpri-lo. Numa outra vertente, tem-se a representação de práticas ritualísticas, porém, desprovida de ascese, isto é, desprovida de uma moldura específica que lhes dê sentido, manifestando somente a pura mecanicidade dos gestos enquanto um fim em si mesmo. É exatamente isso que se torna obsceno na moral kantiana: quando passamos a agir em nome de uma formalidade vazia de conteúdo, em função de um imperativo categórico silencioso, que não delimita ponto ou linha de chegada, a resposta só pode ser o excesso das práticas automatizadas desprovidas de significado. E eis o retrato do universo sadiano: a expressão fria e indiferente das práticas sexuais mecanizadas, desvinculadas de horizonte ou sentido último. E é exatamente isso, de acordo com Zizek (1998), que Lacan identifica como a fantasia fundamental sadiana. Ou seja, enquanto Kant proporciona a bela imagem do dever ético incondicional (o sentimento de respeito proporcionado pela dignidade moral), Sade nos proporciona a imagem do corpo torturado como suporte material desse ideal de beleza. E é exatamente isso que Kant nos omite (e omite a si mesmo): o postulado da imortalidade da alma, numa luta sem fim para alcançar a perfeiçáo ética, é correlato de seu exato oposto, da imortalidade do corpo para suportar, golpe por golpe, dor e humilhação infinita.

Nesse sentido, é crucial destacar que Sade, bem como Kant, busca em seus escritos um formalismo universal. Ou seja, nos rituais sádicos de práticas sexuais extremas, está em jogo uma rejeição radical do patológico, de modo que o produto de suas práticas não corresponde em absoluto à obtenção de satisfação dos desejos imediatos, mas, sim, ao excesso que se encontra para além do princípio de prazer. Desse modo, a mesma apatia que anima o dever da lei moral em Kant serve também como pano de fundo para a máxima sadiana. Portanto, há manifestadamente um desprezo radical pelo sensível e pela resistência do objeto. Isto é, "Sade também está à procura de uma purificação da vontade que a libere de todo conteúdo empírico e patológico." (SAFATLE, 2003, p. 218). É o que assinala, por exemplo, Monique David-Ménard (1998, p. 18), nesta passagem:

Certamente náo é desprovido de pertinência observar que o homem do sublime e da moralidade, o homem kantiano, que coloca o patológico no ritmo da constância dos princípios que a açáo reivindica, se parece com o homem sadiano no que justamente a variabilidade dos objetos pulsionais 
é interpretada por um e pelo outro com uma indiferença - indiferença aos olhos do reino exclusivo dos interesses do gozo para Sade, indiferença no respeito pela lei moral que relega todos os interesses sensíveis numa nãopertinência aos olhos do imperativo para Kant.

\section{UM GOZO PARA ALÉM DO PRINCÍPIO DO PRAZER}

É aqui que passamos a considerar o efeito da jouissance (gozo), um conceito estritamente psicanalítico que articula uma espécie de satisfação que não é da ordem do princípio do prazer. É crucial, portanto, perguntar: há satisfação na dor da humilhação de se submeter infatigavelmente ao imperativo da lei moral? Para a psicanálise, sim. Todavia, essa satisfação náo está associada ao princípio de prazer; trata-se da satisfação da própria pulsão em repetir eterna e ciclicamente um mesmo movimento. E esse é o ponto que está velado em Kant, mas que Lacan enxerga com muita propriedade, nos escritos de Sade. Como afirma Zizek (1992, p. 66), “[...] segundo Lacan, Kant escamoteia o outro lado dessa neutralidade da lei moral, sua maldade e sua obscenidade, sua malignidade que remete a um gozo por trás da ordem da lei”. Ou seja, a força motriz que impulsiona o sujeito ao das Gute, que o faz continuar a obedecer ao imperativo da lei sem o ganho de qualquer benefício calculável para o sujeito, é a jouissance.

Para melhor compreender essa complicada relação entre jouissance e princípio de prazer, tomemos a análise que Lacan faz de uma famosa passagem da Crítica da razão prática. A fim de demonstrar a autonomia da liberdade em seguir o dever moral, em detrimento das inclinaçôes patológicas do sujeito, Kant (2011a, p. 50-51) apresenta o seguinte desafio:

Supondo que alguém alegue que sua voluptuosa inclinação seja-lhe totalmente irresistível no momento em que o objeto querido e a ocasiáo correspondente lhe ocorram, pergunta-lhe se, no caso em que se erguesse perante a casa em que ele encontra essa ocasiáo uma forca para suspendê-lo logo após a gozada volúpia, ele então não dominaria sua inclinação. Não se precisa de muito tempo para adivinhar o que ele responderia.

Ou seja, para Kant (2011a), entre ser enforcado após ter tido a chance de fazer sexo com a mulher de seus sonhos e não fazê-lo, obviamente que o homem escolheria suspender suas inclinaçóes patológicas em favor da vida. É claro que essa representaçáo não corresponde ao que Kant toma como uma atitude verdadeiramente moral, pois está em jogo um cálculo bem-sucedido 
sobre as consequências empíricas de sua escolha. E Lacan está totalmente ciente disso: "[...] isso não é nada, e não é aí que está o fundamento da moralidade em Kant." (LACAN, 1959-60/1988, p. 136). Contudo, é outra coisa que lhe chama a atenção. No fundo, para Lacan, fazer ou não sexo com a mulher não significa respectivamente satisfação ou abstinência dos prazeres. Não está em jogo aqui uma escolha simples que acarreta diretamente em prazer ou desprazer. Pelo contrário, do ponto de vista da psicanálise, a única forma de o sujeito obter prazer é renunciando ou protelando a própria satisfação imediata. Isto é, a escolha do sujeito não se baseia somente nas consequências empíricas de seu ato: o sujeito escolhe a abstinência do sexo, não por temer diretamente a forca, mas porque talvez essa seja a única condiçáo de ele continuar gozando. Essa lógica paradoxal é certamente a principal contribuição da teoria psicanalítica: o que, até Freud, nunca se tinha levado em consideração é o fato de que há uma assimetria profunda entre prazer e gozo. Gozo e princípio de prazer são não princípios antagônicos, mas antinômicos par excellence. $\mathrm{Ou}$ seja, eles não estão situados no mesmo plano linear, mas separados por uma lacuna paraláctica irredutível. E, para que continue havendo desejo, é preciso que haja sempre uma distância mínima entre princípio de prazer (satisfação) e gozo. Assinala Miller (2011, p. 204):

Aqui somos obrigados a fazer uma disjunção entre gozo e satisfação. Não haveria experiência analítica se o gozo fosse satisfatório. É precisamente pelo fato de o verme estar no próprio fruto do gozo que se pode conceber uma análise na qual uma jaculação possa retificar. Retificar náo o sujeito. Tratase de uma retificação do gozo, isto é, que ele se torne, que ele possa ser concebido como satisfatório.

Quer dizer, o verme dentro do fruto significa a própria lacuna que impede um acesso direto ao gozo pela via do prazer.

Segundo Johnston (2005), podemos apontar dois fatores que, do ponto de vista da psicanálise, solapam a tese do filósofo. Primeiramente, Johnston declara que, segundo Lacan, essa escolha não é tão óbvia assim, ou seja, não há na verdade nenhuma necessidade lógica e/ou transcendental para o homem deixar de dormir com a mulher de seus sonhos a fim de evitar o enforcamento. No fundo, está totalmente no seu campo de possibilidade decidir se sacrificar para ter uma noite de extraordinária de prazer. Em segundo lugar, para Lacan (1963/1998), a forca não representa absolutamente um empecilho para o exercício do desejo do homem; com efeito, consiste na própria condição positiva para seu desejo. Ou seja, o objeto de desejo e a forca não são duas categorias 
disponibilizadas num mesmo plano simétrico, onde a possibilidade de ser enforcado após consumar o ato anularia o desejo pela mulher. $\mathrm{Na}$ verdade, há aqui uma assimetria radical entre eles, cujo efeito revelador apresenta um como sendo a condição positiva do outro. Dito sem rodeios: do ponto de vista da psicanálise, o que sustenta o vínculo do sujeito pela mulher é justamente a possibilidade de ser enforcado logo após a táo sonhada "gozada volúpia". Como explica Zizek (1999, p. 289):

O contra-argumento de Lacan aqui é que nós certamente temos de adivinhar o que sua resposta pode ser: e se nós encontrássemos um sujeito (como constata regularmente a psicanálise) que só pode desfrutar plenamente de uma noite de paixão se alguma forma de forca ameaçá-lo - isto é, se, fazendo isso, ele violasse alguma proibição... se a gratificação da paixão sexual envolvesse a própria suspensão dos mais elementares interesses "egoístas" [...] esta gratificação é claramente localizada no "além do princípio do prazer".

Assim, o desafio de Kant não é, como pensava ele, um simples conflito entre princípio de prazer e conservação da vida. $\mathrm{O}$ que ele não levou em consideração é a existência de um terceiro termo que regula todo o processo: o gozo. O ponto paradoxal é que, ao escolher pela abstinência, o homem escolhe ao mesmo tempo pelo princípio do prazer. $\mathrm{E}$ a única condição de ele continuar gozando é abdicando de seu gozo literal, de sucumbir ao pathos de sua inclinação sexual. Todavia, isso só se torna inteligível, se tivermos em mente de que se trata - insisto - de uma relação radicalmente assimétrica entre a donzela e a forca, ou melhor, entre desejo e proibição. Dessa maneira, enquanto, numa dimensão, o sujeito é impedido de entregar-se às suas inclinações patológicas imediatas, na outra, ele goza lascivamente desse mesmo impedimento. Eis o segredo de Kant que Sade nos revela: enquanto, por um lado, seguimos obstinadamente o rigor da lei moral, por outro, gozamos compulsivamente.

Este é o paradoxo básico da jouissance: o fato de ela ser tanto impossível quanto inevitável. Como nos mostra Zizek, por um lado, ela nunca é atingida, é sempre perdida, mas, por outro, nunca nos livramos dela. Ou seja, cada vez que renunciamos ao gozo, gera-se um gozo na renúncia. Com cada empecilho que obstrui o acesso ao desejo, gera-se um desejo por esse mesmo obstáculo “[...] o excesso do gozo não é um resto do gozo que resiste, não importa com que intensidade o sujeito lute para se livrar dele, mas sim um gozo que surge da própria renúncia." (ZIZEK; MILBANK, 2014, p. 310). Por isso, a dialética entre desejo e proibição não significa simplesmente elevar o valor do objeto, tornando seu acesso mais difícil, porém, de maneira propriamente paradoxal, 
tomar esse mesmo objeto como uma força autocontraditória, de atração e repulsão simultânea, gerando, assim, um vazio estrutural por cujo eixo gravita nosso desejo (ZIZEK, 2006b, p. 25).

Assinala claramente Zizek (2008a, p. 89):

É assim também que deveríamos ler a tese de Lacan sobre a "satisfaçáo das pulsōes": a pulsão traz satisfação porque [...] transforma fracasso em triunfo - nela, o próprio fracasso de atingir a meta, a repetiçâo desse fracasso, a circulação sem fim em torno do objeto, gera uma satisfação própria. Como explica Lacan, o verdadeiro alvo da pulsão não é atingir a meta, mas sim circular interminavelmente em torno dela.

\section{O OBJETO $a$}

Desse modo, vê-se que desejo e gozo são categorias radicalmente antagônicas e até exclusivas, uma em relação à outra. No entanto, diante disso, surge uma outra questão pertinente: “[...] como será entâo possível acoplar desejo e gozo para garantir um mínimo de gozo no interior do espaço do desejo?" (ZIZEK, 2004, p. 52). Ou seja, qual seria o elemento mediador dos domínios incompatíveis entre gozo e desejo? A resposta só pode ser uma: o famoso objeto $a$ de Lacan. É, portanto, o objeto $a$ que, por assim dizer, dá as coordenadas elementares que estruturam o quadro de nossa dimensão fenomênica. E, como tal, ele cumpre uma dupla designação: ele é tanto o objeto-causa do desejo como também o objeto-mais gozar. Jacques Alain-Miller (2010, p. 195) é eloquentemente preciso, quando destaca que "[...] o objeto $a$ é um amboceptor entre o desejo e o gozo. Para mostrar isso, nada melhor do que estas duas definiçóes trazidas por Lacan ao longo de sua obra: ele o define tanto como mais gozar quanto como causa do desejo".

Portanto, não nos deixemos enganar: o objeto $a$ não é (somente) o objeto faltante, que sempre escapa ao meu alcance, apto a driblar astuciosamente o meu desejo. Mais que isso, o objeto a é propriamente a falta encarnada que inaugura a própria dimensão do desejo. Assim, ressalta Zizek (2004, p.52): "O objeto pequeno $a$ não é aquilo que desejamos, aquilo que procuramos, mas antes o que póe o nosso desejo em movimento, o quadro formal que lhe dá consistência." Em outras palavras, o objeto a é o objeto-causa da falta ou causa-do-desejo (uma vez que o desejo corresponde a esse processo metonímico) e, como tal, ele não é (somente) um processo dinâmico e fugaz, contudo, constitui a própria presença inerte da falta que nos póe em um pseudomovimento de busca eterna - o eixo fixo que nos faz estupidamente mover em círculo, 
em torno dele. Zizek (2012, p. 384) afirma, em seu Menos que Nada: “[...] o objeto-causa do desejo não é senão a encarnação da falta, seu lugar-tenente. Aqui, a relação entre objeto e falta é invertida: a falta não é redutível à falta de um objeto, ao contrário: o próprio objeto que é a positivação espectral de uma falta."

E, à medida que o objeto $a$ é o objeto que encarna a própria falta em torno da qual circula o nosso desejo, esse objeto estrutural deve então produzir um excesso de gozo, um mais-gozar, que impede o arremate final entre desejo e gozo. Isto é, ele é a distância mínima que articula essas duas dimensóes. Isso se torna menos enigmático, se levarmos em conta a ambiguidade que comporta a expressão francesa plus-de-jouir. O plus aqui pode significar tanto "mais", "excesso", como também "não mais", "nenhum" (dependendo apenas da forma como é pronunciado). Isso significa que o mais-gozar é tanto aquilo que produz gozo, mas também aquilo que impede o acesso ao gozo. "Nesse sentido, o excesso de gozo sobre o mero prazer é gerado pela presença do exato oposto do prazer, ou seja, a dor." (ZIZEK, 2012a, p. 164).

O mais-gozar é, por conseguinte, o próprio gozo na dor, ou seja, quando almejamos obter um excesso de prazer, o resultado é que já não temos mais nenhum prazer, pelo simples motivo de que só podemos experimentá-lo como dor. Em suma: temos entáo uma relação antinômica entre gozo e desejo, cujo mediador é justamente o objeto $a$. Dessa maneira, é correto afirmar que o desejo constitui a dimensão fenomênica do infinito espúrio, na qual o sujeito trafega incessantemente numa estrada sem fim, em busca de sua satisfação plena, ou seja, de seu gozo absoluto. No entanto, o que passa despercebido para esse sujeito é o fato de que o gozo não se encontra na dimensão tempoespacial da realidade fenomênica, na linha de chegada dessa estrada, mas se apresenta de maneira inerte e ininterrupta justamente nessa própria busca eterna e frustrante. Consequentemente, esse gozo só pode ser obtido na forma de um mais-gozar, na medida em que é frustrado no próprio campo do desejo. Assim, longe de ser uma concepçáo metafísica do gozo, para a psicanálise, desejo e gozo são, a rigor, um só princípio, separado de si mesmo por uma lacuna paraláctica: o objeto $a$. Enfatiza Zizek (2008b, p. 55): "[...] o objeto $a$ é o rochedo, o obstáculo que interrompe o fechamento do circuito do "princípio do prazer' e descarrila seu movimento equilibrado".

Cabe fazer, neste ponto, uma pergunta trivial, porém, extremamente reveladora: se o objeto a é o objeto-causa do desejo, isto é, o objeto que garante as coordenadas básicas segundo as quais o sujeito se inscreve no campo 
do desejo, por que razão continuar chamando-o de objeto, e não apenas de quadro categorial do desejo? Em outras palavras, se ele náo consiste num objeto ordinário do nosso desejo, mas naquilo que inaugura o próprio campo do desejo, então ele, mais do que um objeto, consiste na própria dimensão transcendental do desejo. Correto. Entretanto, devemos novamente encarar aqui mais uma inversão dialética radical: a problemática que o objeto $a$ levanta não é apenas a problemática do idealismo transcendental kantiano, cuja ênfase reside no horizonte transcendental da realidade fenomênica, mas, de forma essencialmente hegeliana, Lacan procura capturar a dimensão ontológica do transcendental inscrito na própria realidade fenomênica. Em outras palavras, o objeto $a$, justamente por ser o mediador entre gozo e desejo, é ele, para utilizar uma expressão foucaultiana, um duplo empírico-transcendental. Desse modo, ao mesmo tempo em que o objeto $a$ é a causa transcendental do desejo, ele é reificado no próprio campo espaço-temporal do desejo razão pela qual não se pode pensá-lo nem somente em sua condição ôntica, nem somente em sua dimensão ontológica, como horizonte de significado do ser. Seu estatuto é literalmente ôntico-ontológico, cujo protótipo segue o princípio do juízo especulativo hegeliano: "O Espírito é um osso", "Deus é Cristo" etc.

Isso explica sua dupla designação: como objeto-causa do desejo, ele cumpre essa função transcendental mais elevada, ao passo que, como objeto-mais-gozar, ele cumpre o excesso ôntico inapreensível pelo quadro do transcendental do desejo. Por isso, Lacan procura igualmente diferenciar o objeto a da Coisa numenal (das Ding-en-sich kantiano, ou das Ding freudiano): enquanto a Coisa consiste no excedente numênico que extrapola os limites de minhas capacidades transcendentais de apreensão e conceitualização, o objeto $a$ é esse próprio limite transcendental reificado. Ele é, por assim dizer, a borda que delimita o espaço da subjetividade. A grande dificuldade para apreender o verdadeiro significado da ideia de objeto $a$ é, pois, identificar num mesmo conceito tanto a forma a priori que abre o campo metonímico do desejo, como o excesso ôntico irredutível a essa falta.

\section{O imperativo do gozo}

Voltemos, então, para nosso tema fundamental: a relação íntima e paradoxal entre Kant e Sade. Como vimos, o esforço lacaniano na leitura de Kant com Sade nada mais é do que revelar o objeto de gozo excessivo oculto na Crítica da Razão Prática. Foi, portanto, Sade quem revelou o fato de que o sujeito moral kantiano não é de modo algum uma totalidade harmônica idên- 
tica a si mesma, mas, em última instância, um sujeito radicalmente clivado em seu cerne. A voz da consciência, a qual exprime a lei moral, não é uma voz clara e distinta, como acreditava Kant: é uma voz dissonante e estrangeira, cujo efeito é um estranhamento inconciliável do sujeito consigo mesmo. É como se o imperativo du kannst, denn du sollst! (podes, porque deves!), que emerge ininterruptamente na consciência moral, provocasse, por sua condição puramente formal, uma exigência aterradora e monstruosa, uma necessidade compulsiva de purificação e aniquilação de todo conteúdo empírico. E o resultado disso é o absurdo ético supremo: tendo em vista a inflexibilidade do imperativo categórico, o Bem supremo do dever ético universal se confunde com a perversidade maligna do gozo destrutivo. Nos termos de Zizek (1988, p. 66), “[...] a lei moral é uma ordem feroz que não admite desculpas - 'podes, porque deves' - e que ganha, por isso, o ar de uma neutralizada malfazeja, uma indiferença malévola." Desse modo, pode-se concluir que a voz silenciosa e intransigente da consciência é uma voz monossilábica e repetitiva que emite uma só ordem: goze!

O mérito de Sade, portanto, foi ter revelado essa cisão constitutiva do sujeito, a voz como o objeto que cinde o sujeito entre gozo e desejo. E, neste ponto, cumpre introduzir a ambiguidade constitutiva do conceito de supereu para Lacan. O supereu, identificado com o próprio princípio formal da Lei moral, é justamente o princípio que desperta esse excesso libidinal: é o próprio vazio formal da Lei moral o agente da transgressão, que impele o sujeito ao gozo. Nesse sentido, "[...] o supereu é uma lei enlouquecida, na medida em que pró́be o que formalmente permite.” (ZIZEK, 2006b, p. 194). Ou, ainda:

O supereu é uma Lei na medida em que não está integrado no sistema simbólico do sujeito, na medida em que sua função como ordem incompreensível, sem sentido, traumática, incomensurável com a riqueza psicológica das atitudes afetivas do sujeito, manifesta uma espécie de "neutralidade malevolente" dirigida contra o sujeito, indiferente às suas empatias e temores. Neste ponto preciso, à medida que se confronta com a "instância da letra" [no caso, o Significante-Mestre $\left.\left(S_{1}\right)\right]$ na sua exterioridade original e radical, com o sem-sentido do significante no seu estado mais puro, o sujeito depara-se com a ordem do supereu "Goza!", que se dirige ao núcleo mais íntimo do seu ser. (ZIZEK, 2006b, p. 133).

Ou seja, aqui, a forma pura da Lei e transgressão se confundem. $\mathrm{Na}$ medida em que a Lei se aproxima de sua forma pura, de seu vazio formal, somos fatalmente compelidos ao seu gozo obsceno, à jouissance que expressa 
isso que Zizek chamou acima de "neutralidade malevolente". Quer dizer, a formalidade da Lei moral universal, sua obsessão implacável por uma total depuração de todo e qualquer conteúdo patológico é, paradoxalmente, sua transgressão imanente, seu excesso incontido que destrói justamente aquilo mesmo que se quer preservar.

\section{KANT SEM SADE}

Embora tenhamos feito até aqui todo esforço para aproximar a filosofia prática de Kant da injunção ao gozo, em Sade, de maneira que se torna cada vez mais claro para nós o quanto o vazio da Lei moral é intrinsecamente correlato de sua transgressáo constituinte, a esta altura é oportuno desfazer esse laço e pensar uma possibilidade de considerar um Kant sem Sade. Isto é, evidentemente, o modo com que a pura forma da Lei moral kantiana foi conduzida até aqui nos fez perceber como o sujeito da Lei moral não é uno, idêntico a si mesmo, como acreditava Kant, mas, no que concerne ao exercício de seu dever, ele é radicalmente cindido entre desejo e gozo. No entanto, agora devemos ir com calma, pois esse não é o ponto final da história. A pergunta-chave, porém, passa a ser: estaremos condenados eternamente ao paradoxo de Kant com Sade, ou seja, a essa repetição demoníaca entre desejo/frustração e gozo? Estaremos condenados a gozar na dor e na humilhação de nosso fracasso? Será que a resposta final da moral kantiana consiste, de fato, na fórmula do supereu obsceno da injunção ao gozo? Se a resposta for "sim", devemos aceitar o fato de que Sade realmente representa a verdade do projeto moral de Kant. Contudo, se a resposta for "não", significa que deveríamos encontrar uma saída para o projeto da filosofia prática de Kant que não corresponda à lógica do supereu e que, nesse sentido, Sade passasse a representar apenas o aspecto pervertido da Lei moral kantiana. Todavia, isso não significa que devemos regredir de Sade a Kant (e desmentir seu elo imanente), mas, pelo contrário, devemos confrontar Kant com ele mesmo, encontrar no próprio impulso criativo da filosofia kantiana o núcleo que excede seu próprio edifício teórico e, assim, fazer Kant avançar sobre Sade. Daí a importância em fazer jus à intuição fundamental de Kant e radicalizar o princípio de autonomia humana. Porém, para isso, é preciso trair a letra de Kant, para assim ser fiel a seu espírito. Cumpre, desse modo, efetuar aqui um passo decisivo: devemos abandonar o modelo formal-transcendental kantiano para alcançar um nível mais profundo de autonomia e liberdade; é preciso, em outras palavras, que o vigor do imperativo categórico kantiano, isto é, o abandono completo de toda lei heterônoma que bloqueia 
a extensão da autonomia moral, alcance uma força ainda mais aguda e, dessa forma, o sujeito se aproprie do próprio núcleo subversivo da Lei moral, de seu gozo subjacente. Mas de que maneira?

Se quisermos recuperar a intuição fundamental de Kant, devemos radicalizar ainda mais a lógica do sacrifício imposto pelo rigor moral. Quando Freud articulou o conceito de supereu, ele o associou diretamente com um sentimento de culpa inassimilável. Para Freud (1923/2011), quanto mais o sujeito se submete à inflexibilidade do supereu, maior a pressão e mais ele se sente culpado - quanto mais cumpre o seu dever, maior o peso da culpa sobre seus ombros. Ou seja, o efeito paradoxal é que o sentimento de culpa jamais pode ser dissipado com o cumprimento da Lei imposta pelo supereu. E Lacan faz a leitura correta desse paradoxo, conforme assevera Zizek (2006b, p. 196):

No entender de Lacan, esse sentimento de culpa não é uma ilusão que deva dissipar-se no decorrer da cura psicanalítica: realmente somos culpados; o supereu extrai a energia necessária para pressionar o sujeito do fato de este não ser fiel ao seu desejo e haver cedido. $\mathrm{O}$ nosso sacrifício ao supereu, o tributo que lhe pagamos, só confirma a nossa culpa. E é por isso que a nossa atividade para com o supereu náo tem remissáo: quanto mais pagamos, mais devemos. O supereu é como o chantagista que nos vai lentamente sangrando até a morte; quanto mais obtém, maior influência tem sobre nós.

E qual é o significado disso? Significa que, se o sentimento de culpa ainda persiste, embora se obedeça rigorosamente à necessidade de sacrifício em nome da Lei, isto testemunha o fato de que algo ainda continua a ser comprometido, quer dizer, atesta somente que o sacrifício ainda não fora suficientemente radical. Por conseguinte, o que poderia ser sacrificado, além de todo sacrifício exercido em função da Lei moral? Resposta: o próprio sacrifício em si, ou (o que dá no mesmo) o sacrifício do gozo. Uma vez que a fórmula básica da agência do supereu maligno é o sacrifício de todo conteúdo empírico, em nome da pura forma da Lei, o passo seguinte para radicalizar o princípio absoluto do sacrifício, imposto pela Lei moral, seria, então, sacrificar a própria forma da Lei, ou seja, sacrificar o próprio sacrifício. Num primeiro momento, o sujeito sacrifica tudo em nome da exigência do próprio sacrifício, restando disso um gozo inaudito articulado pelo próprio ato de sacrificar. Mas, num segundo momento, como consequência lógica do primeiro ato, o sujeito deve sacrificar o próprio sacrifício, ou seja, o próprio gozo incutido na compulsão da injunção ao sacrifício. 
Nesse sentido, é imprescindível remover o âmbito da ética para além da tensão entre Lei e gozo. Cabe, pois, opor o que Lacan considera como a ética do desejo, na psicanálise, cuja máxima é "não cedas no teu desejo", à injunção ao gozo exercida pelo supereu. À primeira vista, parece haver uma contradição nessa máxima lacaniana, uma vez que o desejo, como foi tratado ao longo deste capítulo, é a condição de possibilidade (negativa) do gozo. No entanto, devemos considerar que o gesto conclusivo do desejo, seu acabamento final, não é o encontro satisfatório com o objeto (uma vez que isso é impossível), mas o sacrifício de si, ou seja, o desejo deve sacrificar a própria causa que põe em atividade o circuito metonímico através da qual ele busca satisfação. Em outras palavras, embora o desejo seja caracterizado por uma perda constitutiva a priori, isto é, por uma eterna e incessante procura por seu objeto perdido, a sua ética mais fundamental não pode consistir na manutenção desse movimento incessante em torno desse vazio. A ética do desejo consiste, ao contrário, na perda da própria perda, ou seja, na negação da negação, a via através da qual se nega a própria causa-da-negação que dá origem ao desejo. Isso nos leva ao conceito lacaniano de "travessia da fantasia". Para entendê-lo, temos que justapor dois tipos de negatividade: a primeira delas é ocasionada pelo engodo da posição subjetiva que incorpora a negatividade/finitude como dimensão metonímica do desejo. Mediante essa postura, surge inevitavelmente o sentimento de uma perda originária e constitutiva, uma falta jamais suprida. A segunda negatividade, todavia, é uma inversão dialética da própria perda, isto é, perda dessa perda originária: não é que o sujeito perca algo positivo, um objeto determinado cuja falta determinará o sentido de sua existência; mas o que ele perde é exatamente o que nunca possuiu, ou seja, ele perde a ilusão subjetiva de que antigamente possuía algo. E o sentimento de culpa, que acompanha o supereu, é a confirmação inequívoca de que essa travessia (da fantasia) ainda não foi definitiva, e que o desejo ainda é comprometido de alguma forma.

Qual, então, a relação disso com a moral kantiana? Ora, o ponto falho da moral transcendental de Kant é justamente quando ele não tematiza essa inversão dialética em que, para que se alcance a verdadeira dimensão da liberdade, tanto o conteúdo patológico que mancha a pura forma da Lei moral deve ser sacrificado, como também - e sobretudo - a própria forma da Lei moral deve ser sacrificada. Por esse motivo, Zizek insiste no fato de que Sade não é a verdade última de Kant, mas apenas o sintoma de Kant em haver cedido em sua intuição ética primordial, cedido em seu desejo de enfrentar as consequências de sua revolução moral. Zizek (2011a, p. 215) afirma claramente: 
Devemos inverter a leitura mais comum do lacaniano "Kant com Sade", segundo a qual a perversão sadiana é a "verdade" de Kant, mais "radical" do que Kant, e deduz as consequências que o próprio Kant não teve coragem de enfrentar. Mas deveríamos afirmar o contrário: a perversão sadiana surge como resultado da acomodação kantiana, do fato de Kant evitar as consequências de sua descoberta. Sade é o sintoma de Kant: embora seja verdade que Kant recuou para não exprimir todas as consequências de sua revolução ética, foi essa acomodaçáo de Kant, essa falta de vontade de ir até o fim, de ser totalmente fiel à sua descoberta filosófica, que abriu espaço para a figura de Sade. Longe de ser simples e diretamente a "verdade" de Kant, Sade é o sintoma de como Kant traiu a verdade de sua própria descoberta - o obsceno jouisseur sadiano é um estigma que testemunha a acomodação ética de Kant; o "radicalismo" aparente desse personagem (a disposição do herói sadiano de ir até o fim em sua Vontade-de-Gozar) é uma máscara do extremo oposto. Em outras palavras, o verdadeiro horror não é a orgia sadiana, e sim o âmago real da própria ética kantiana.

Por isso é que somente assumindo a jouissance oculta por trás da forma pura da Lei moral é que podemos pensar um Kant desprovido de seu excesso obscuro e, assim, finalmente, quebrar o círculo vicioso entre Kant e Sade. E é somente ao sobrepor a crítica do desejo puro de Lacan à Crítica da Razáo Prática de Kant é que podemos radicalizar o princípio da liberdade humana. $\mathrm{E}$, como ficou claro, esse desejo puro só pode ser efetivado com a identificação plena do sujeito transcendental com o seu resto excrementício enquanto maisgozar. Ou seja, somos livres apenas quando nos identificamos com o complemento objetal da falta, isto é, o objeto a como o fundamento da pura formalização do sujeito transcendental.

FONSECA, Fernando Facó de Assis; RECH, Hildemar Luiz. Zizek with Lacan in Kant without Sade: freedom as the reappropriation of pleasure. Tans/form/ação, Marília, v. 40, n. 1, p. 165-186, Jan./Mar., 2017.

\begin{abstract}
In this article, based on a reading of Zizek and Lacan, we discuss the radical perspective of freedom as an overcoming of the dialectic between the Kantian moral law and sadistic joy. We first try to show how Lacan articulates Kant's relationship with Sade, and then consider how, according to Zizek, the psychoanalyst finds an outlet for the Kantian principle of freedom based the ethics of pure desire, which allows us to think of a Kant without Sade.
\end{abstract}

KeYwords: Moral law. Desire. Enjoyment. Freedom. 


\section{REFERÊNCIAS}

BACON, F. Novo órganon [Instauration Magna] São Paulo: Edipro, 2014.

DAVID-MÉNARD, M. A construção do universal. Rio de Janeiro: Companhia de Freud, 1998.

FERRY, L. Kant: uma leitura das três “Críticas”. Rio de Janeiro: DIFEL, 2012.

FREUD, S. O eu e o id. In: . Obras completas, v. 16. São Paulo: Companhia das Letras, 2011. (Original publicado em 1923).

HEGEL, G. W. F Fenomenologia do espírito. Rio de Janeiro: Vozes, 2003.

JOHNSTON, A. Time Driven: metapsychology and the splitting of the Drive Evanston. Northwestern: University Press, 2005.

KANT, I. Anthropology, history and education. New York: Cambridge University Press, 2007.

. A metafisica dos costumes. São Paulo: Edipro, 2008.

. Crítica da razão prática. São Paulo: Martins Fontes, 2011a.

. Fundamentação da metafísica dos costumes. Lisboa: Edições 70, 2011 b.

LACAN, J. Subversao do sujeito e dialetica do desejo no inconsciente freudiano. In: Escritos. Rio de Janeiro: Jorge Zahar, 1998. p. 807-842.

O seminário, Livro 7: a ética da psicanálise. Rio de Janeiro: Jorge Zahar, 1988. (Original 1959/1960).

MILLER, J. A. Perspectivas dos escritos e outros escritos de Lacan: entre desejo e gozo. Rio de Janeiro: Zahar, 2011.

SAFATLE, V. O ato para além da lei: Kant com Sade como ponto de viragem do pensamento lacaniano. In: (Org.). Um limite tenso: Lacan entre a filosofia e a psicanálise. São Paulo: Editora da UNESP, 2003. p. 189-232.

ZIZEK, S. O mais sublime dos histéricos: Hegel com Lacan. Rio de Janeiro: Jorge Zahar, 1988.

Zahar, 1992.

Eles não sabem o que fazem: o sublime objeto da ideologia. Rio de Janeiro: Jorge

. Kant and Sade: the ideal couple. Lacanian Ink, Nova York, 13, p. 12-25, Fall,1998. Disponível em: <http://www.lacan.com/cover13.htm>. Acesso em: 20 nov. 2016.

. Kant with (or against) Sade. In: WRIGHT, E.; WRIGHT, E. (Ed.). The Zizek Reader. Oxford: Blackwell, 1999. p. 281-301.

- A subjetividade por vir. Lisboa: Relógio d'Água, 2004.

- As Metástases do gozo: seis ensaios sobre a mulher e a causalidade. Lisboa: Relógio

d'Água, 2006b. 
FONSECA, F. F. A.; RECH, H. L.

- A visão em paralaxe. São Paulo: Boitempo, 2008a.

Enjoy your symptom! Enjoy your symptom!: Lacan in Hollywood and Out. New York; London: Routledge, 2008b.

. Órgãos sem corpo: Deleuze e conseqüências. Rio de Janeiro: Companhia de Freud, 2011a.

2012a.

. Menos que nada: Hegel e a sombra do materialismo dialético. São Paulo: Boitempo,

; MILBANK, J. A monstruosidade de Cristo. São Paulo: Três Estrelas, 2014.

Recebido em 20/07/2016

Aceito em 21/10/2016 